\title{
Plant functional types and traits as biodiversity indicators for tropical forests: two biogeographically separated case studies including birds, mammals and termites
}

\author{
Andrew N. Gillison • David E. Bignell • Kenneth R. W. Brewer • \\ Erick C. M. Fernandes - David T. Jones - Douglas Sheil • \\ Peter H. May • Allan D. Watt • Reginaldo Constantino • \\ Eduardo G. Couto - Kurniatun Hairiah • Paul Jepson • \\ Agus P. Kartono - Ibnu Maryanto • Germano G. Neto • \\ Meine van Noordwijk • Elton A. Silveira • Francis-Xavier Susilo • \\ Stephen A. Vosti $\cdot$ Paulo C. Nunes
}

Received: 21 March 2013/Accepted: 21 June 2013/Published online: 12 July 2013

(C) The Author(s) 2013. This article is published with open access at Springerlink.com

\begin{abstract}
Multi-taxon surveys were conducted in species-rich, lowland palaeotropical and neotropical forested landscapes in Sumatra, Indonesia and Mato Grosso, Brazil. Gradient-directed transects (gradsects) were sampled across a range of forested land use mosaics, using a uniform protocol to simultaneously record vegetation (vascular plant
\end{abstract}

Electronic supplementary material The online version of this article (doi:10.1007/s10531-013-0517-1) contains supplementary material, which is available to authorized users.

A. N. Gillison ( ()

Center for Biodiversity Management, P.O. Box 120, Yungaburra, QLD 4884, Australia

e-mail: andygillison@gmail.com

D. E. Bignell

Institute for Tropical Biology and Conservation, Universiti Malaysia Sabah, 88999 Kota Kinabalu, Sabah, Malaysia

e-mail: d.bignell@qmul.ac.uk

Present Address:

D. E. Bignell

School of Biological and Chemical Sciences, Queen Mary, University of London, London E1 4NS, UK

K. R. W. Brewer

School of Finance and Applied Statistics, Australian National University, Canberra, ACT 0200,

Australia

E. C. M. Fernandes

The World Bank, I6-603, 1818 H Street, Washington, DC 20433, USA

D. T. Jones

Soil Biodiversity Group, Department of Entomology, The Natural History Museum, Cromwell Road, London SW7 5BD, UK 
species, plant functional types (PFTs) and vegetation structure), vertebrates (birds, mammals) and invertebrates (termites), in addition to measuring site and soil properties, including carbon stocks. At both sites similar correlations were detected between major components of structure (mean canopy height, woody basal area and litter depth) and the diversities of plant species and PFTs. A plant species to PFT ratio [spp.:PFTs] was the best overall predictor of animal diversity, especially termite species richness in Sumatra. To a notable extent vegetation structure also correlated with animal diversity. These surrogates demonstrate generic links between habitat structural elements, carbon stocks and biodiversity. They may also offer practical low-cost indicators for rapid assessment in tropical forest landscapes.

Keywords Biodiversity indicators - Tropical forest - Plant functional types - Habitat characterization $\cdot$ Rapid biodiversity assessment $\cdot$ Fauna

\section{Introduction}

Tropical forests contain much of the world's terrestrial biodiversity and significant carbon stocks (Bunker et al. 2005). Particular interest centres on assessing the biodiversity value of modified and disturbed forest ecosystems and the ability of such systems to buffer biodiversity losses expected with the degradation or conversion of more pristine habitats (Wright and Muller-Landau 2006; Chazdon et al. 2009). A complete inventory of

D. Sheil

School of Environmental Sciences and Management, Southern Cross University, P.O. Box 157, Lismore, NSW 2480, Australia

\section{Present Address:}

D. Sheil

Institute of Tropical Forest Conservation (ITFC) at Ruhija, Bwindi Impenetrable National Park, P.O. Box 44 Kabale, Uganda

D. Sheil

Center for International Forestry Research (CIFOR), Sindangbarang, Bogor 16000, Indonesia

P. H. May

Depto de Desenvolvimento, Agricultura e Sociedade, Universidade Federal Rural do Rio de Janeiro, Av. Presidente Vargas, 417-9 ${ }^{\circ}$ andar, Rio de Janeiro, RJ 20072-030, Brazil

A. D. Watt

Centre for Ecology and Hydrology, Bush Estate, Penicuik, Midlothian EH26 0QB, Scotland, UK

R. Constantino

Departamento de Zoologia, Universidada de Brasília, Brasília, DF 70.910.900, Brazil

E. G. Couto

Faculdade de Agronomia e Medicina Veterinária, Universidade Federal de Mato Grosso,

Boa Esperança, Cuiabá, MT 78.060.090, Brazil

K. Hairiah

Faculty of Agriculture, Brawijaya University, Jl. Veteran, Malang 65145, Indonesia

P. Jepson

Environmental Change Institute, University of Oxford, Oxford OX1 3TB, UK 
organisms is not feasible (Lawton et al. 1998), but conservation management can benefit from the identification of any surrogate that broadly predicts overall biodiversity by reflecting the major determinants of taxonomic variety and species richness (Meijaard and Sheil 2012). One approach is to find and use easily assessed indicators (partial measures or estimator surrogates, sensu Sarkar and Margules 2002). However, selection of such indicators remains predominantly intuitive rather than evidence-based (Howard et al. 1997; Lawton et al. 1998; Watt 1998; Noss 1999; Dudley et al. 2005; Kessler et al. 2011; Le et al. 2012) and there remains the challenge of distinguishing change that can be attributed to external anthropogenic factors from underlying natural processes (Magurran et al. 2010). Candidate indicators such as landscape metrics, remotely-sensed variables, multi-species indices and formulated measures of ecosystem complexity or genetic diversity have found wide application but are of limited practicality in forests (UNEP-CBD 1996; Kapos et al. 2001; Delbaere 2002; European Academies' Science Advisory Council (ESAC) 2004; Gregory et al. 2005; Duraiappah and Naeem 2005). Thus forest biodiversity surveys still maintain a taxonomic focus even though the costs of obtaining sufficient sampling can be high and the utility of any one species, or another single taxon, as a predictor of others remains uncertain (Lawton et al. 1998; Watt et al. 1998; Dufrêne and Legendre 1997; UNEP/CBD 2003; Gregory et al. 2005, but see also Schulze et al. 2004). Further, at large spatial scales where within-region diversity is large, higher level taxa (up to family level) must often be used (Villaseñor et al. 2005), but even this is only justifiable where extensive species data are already available (Sarkar et al. 2005). Such difficulties in forests contrast with intensively sampled, relatively species-poor, temperate agricultural lands where

Present Address:

P. Jepson

School of Geography and the Environment, University of Oxford, South Parks Road, Oxford OX1 3QY, UK

A. P. Kartono

Department of Forest Resources, Conservation and Ecotourism, Faculty of Forestry, Bogor Agricultural University, Darmaga, Bogor 16680, Indonesia

I. Maryanto

Zoology Museum, Research and Development Center for Biology (LIPI), J1. Juanda 22,

Bogor 16122, Indonesia

G. G. Neto

Depto Zoológico, Instituto de Biociências, Universidade Federal de Mato Grosso, Av. Fernado Correa da Costa, Coxipó da Ponte, Cuiabá, MT 78.060.900, Brazil

M. van Noordwijk

World Agroforestry Centre, P.O. Box 161, Bogor 16001, Indonesia

E. A. Silveira

Secretaria de Estado de Meio Ambiente do Estado de Mato Grosso, Palacio Paiaguas Rua C, Cuiabà, MT 78.050.970, Brazil

F.-X. Susilo

Department of Plant Protection, Faculty of Agriculture, Lampung University, Jl. Prof. Dr. Sumantri Bojonegoro No. 1, Bandar Lampung, Indonesia

S. A. Vosti

Department of Agricultural and Resource Economics, University of California, Davis, One Shields Avenue, Davis, CA 95616, USA 
single surrogate species may be indentified (e.g. MacNally and Fleishman 2004; Sauberer et al. 2004) or where easily determined land use parameters such as the extent of adjacent semi-natural habitats, or the incidence of fertilizer use, predict broad species richness (Billeter et al. 2008).

While simple, cost-effective indicators are required (UNEP-CBD 1996; Duraiappah and Naeem 2005), an evidence-based procedure for their evaluation remains elusive. To address this problem, and mindful that validation requires reference baselines based on comprehensive species inventories (Delbaere 2002; UNEP/CBD 2003), we hypothesize that the best indicators for forest or forest-derived ecosystems will be those fundamental characteristics of the plant community that are clearly linked to ecosystem performance. For this reason, both taxonomic and adaptive (functional) plant characteristics were used to sample gradient-based forested landscape mosaics in well-characterized sites in Sumatra, Indonesia and Mato Grosso, Brazil. This approach treats taxonomic and functional characteristics as complementary elements of biodiversity (Folke et al. 1996; Duckworth et al. 2000; Loreau et al.2001; Kleyer 2002; Gillison 2000, 2006), and proposes that such a typology may be better suited than taxa alone for ecological comparison (Folke et al. 1996; Gillison 2013). The work described in the present paper examines pristine and modified forest systems, testing the hypothesis that vegetation structure and traits are predictive of plant and animal species diversity and abundance, and demonstrates that plant functional type (PFT) diversity, mean canopy height, woody basal area and litter depth have potential as indicators of biological diversity. We also show that the ratio spp.:PFTs might predict animal species richness. A preliminary study of plant functional traits and termite occurrence in Sumatra sites (only) was published by Gillison et al. (2003). It is argued that forest biodiversity is best addressed within the context of landscape dynamics where ecosystem performance is driven by the interconnectivity of biota across forest and non-forest components of landscape mosaics, i.e. given that the future of much tropical forest is to become multiple land use sites in which some pristine stands remain as reservoirs, the design of the mosaic and the choice of the land uses will determine the extent to which the whole landscape can retain its biota. The present study shows that the indicators we have detected at local regional scale also apply across widely separated biogeographic zones.

\section{Methods}

\section{Study areas}

The Sumatran study area of $3,095 \mathrm{~km}^{2}$ was located in Jambi Province, Central Sumatra $\left(102^{\circ} 00^{\prime}-102^{\circ} 22^{\prime} \mathrm{E}, 1^{\circ} 00^{\prime}-1^{\circ} 40^{\prime} \mathrm{S}\right.$; 30-240 m elevation; $23-33{ }^{\circ} \mathrm{C}$ mean annual air temperature, 55-94\% RH, mean annual precipitation 2,000-3,000 mm, Köppen Af). The Brazilian study included the Cotriguaçu, Juruena and Castanheira municipalities in the northwest Mato Grosso covering $11,350 \mathrm{~km}^{2}\left(9^{\circ} 44^{\prime} 18^{\prime \prime}-10^{\circ} 57^{\prime} 45^{\prime \prime} \mathrm{S}, 58^{\circ} 10^{\prime} 28^{\prime \prime}-10^{\circ} 57^{\prime} 01^{\prime \prime} \mathrm{W} ; 80-300 \mathrm{~m}\right.$ elevation; $17-34.5{ }^{\circ} \mathrm{C}$ mean annual air temperature; $25.4-97.5 \% \mathrm{RH}$, mean annual precipitation 2,000-2,200 mm, Köppen Aw), with a more pronounced dry season than Jambi (Fig. S1 and Tables S2 and S3, Online Resources). The seasonal, continental climate and geomorphology of Mato Grosso, with lowland and upland landforms and widespread cattle grazing,

P. C. Nunes

ADERJUR, Juruena, Mato Grosso, CEP 78.340.000, Brazil 
differ from the less seasonal and more homogeneous, lowland terrain of island Sumatra with its more intensive land use and higher human population density.

\section{Sources of background information}

The work described arises from two large scale projects supported by (amongst others) The World Bank, UNDP, UNEP and the Global Environmental Facility (GEF).The Sumatran study was conducted as part of the Forest Ecosystem Management research program at the Center for International Forestry Research (CIFOR, www.cifor.org), Bogor, Indonesia in collaboration the Alternatives to Slash and Burn program (ASB), implemented by the World Agroforestry Centre (www.worldagroforestry.org). ASB was established in 1992 to halt destructive forms of shifting cultivation and promote sustainable land management at tropical forest margins (Palm et al. 2005; Sanchez et al. 2005). In Brazil, Promoting Biodiversity Conservation and Sustainable Use in the Frontier Forest of Northwestern Mato Grosso was established in 2000 to reconcile socioeconomic development with biodiversity conservation in an integrated landscape containing intact primary forest, corridors of secondary regrowth, forest plantations and intensive agrisilvipasture (Global Environmental Facility 2000). The Mato Grosso sites are included in the project benchmarks, where work is supported by Mato Grosso State Foundation for the Environment, Mato Grosso State Corporation for Rural Technical Assistance and Extension (www. empaer.mt.gov.br), Brazilian Corporation for Agricultural and Livestock Research (www.embrapa.br/english), and World Agroforestry Centre. Brazilian sites are listed by PN number (Pró-Natura, www.pronatura.org).

\section{Gradsects}

Both regions were sampled using gradient-directed transects ("gradsects", sensu Gillison and Brewer 1985). In this approach, sampling locations (sites for $40 \times 5 \mathrm{~m}$ and other transects) are identified within a gradient which represents the sequence of natural and human-modified environments, stratified at nested scales from landscape to plot level (Gillison and Brewer 1985; Wessels et al. 1998; Knollová et al. 2005; Parker et al. 2011). While gradsects approximate "disturbance gradients" in previous usage (e.g. Eggleton et al. 1995; Lawton et al. 1998), in the present study they also opportunistically comprise a series of sites defined variously and hierarchically by climate, land cover, drainage, estimated land use intensity and geological and soil substrata (see Appendix S1, Online Resources). To identify a suitable set of sampling locations, we used aerial and ground traverses, supplemented by satellite imagery, aerial photographs and topographical, vegetational, geological and soil maps. Efforts were made to cover the full range and combinations of all the major environmental, management and historical factors.

In Sumatra, perceived land use intensity gradients ranged from relatively intact humid lowland forest, unlogged as well as logged, through other wooded sites such as softwood and rubber plantations to secondary growth 'Belukar', domestic food gardens and degraded grassland (Gillison 2000). In Mato Grosso, gradients encompassed relatively intact and logged humid lowland forest on deep soil and upland primary forest on exposed granites, savanna-like woodland on seasonally flooded sandstone pavement, dense 'Campinarana' secondary vegetation on forest margins, teak plantations, 'Capoéira' secondary forest and degraded cattle pastures (Gillison 2005; Tables S2, S3, Online Resources). At each sampling site in both regions a $40 \times 5 \mathrm{~m}\left(200 \mathrm{~m}^{2}\right)$ transect (the base transect) served as a focal point for intensive sampling of soils, vegetation and fauna (Anderson and Ingram 1993; 
Swift and Bignell 2001). Transects were located away from habitat boundaries to minimize edge effects. In Mato Grosso 32 transects were documented for vegetation and soils with representative transect subsets sampled for fauna (16 for mammals, birds and reptiles; 11 for termites). In Sumatra 16 transects were documented for vegetation, with representative transect subsets for fauna (15 for birds and mammals, seven for termites). To reduce problems associated with site disturbance by observers, survey work was undertaken in the order vegetation, birds, mammals, carbon stocks, soil (for analysis), termites (from soil and litter). Soils and vegetation were sampled within the base transect; birds, mammals and termites (Sumatra study) adjacent to this transect within the same land use (see below, and Swift and Bignell 2001). Individual plots were selected jointly by vegetation and fauna teams following an initial reconnaissance and site selection for vegetation survey. In each region, search effort and timing were consistent at all transects.

Vegetation

In each base transect we recorded all vascular plant species, including epiphytes where possible. Voucher collections for each species were subsequently identified by botanical staff at the Herbarium Bogoriense in Indonesia and in Brazil at the Botany Department, Instituto de Biociências, Universidade Federal de Mato Grosso, Cuiabá. Unidentified species were allocated unique morpho-species names. Plant functional types (PFTs) and vegetation structure were assessed using a standardized protocol and a generic set of 36 readily observable plant functional elements (PFEs) (Gillison 2002, Table S1, Online Resources). Each unique combination of PFEs defines a specific PFT that can be expressed using a formal grammar: thus a plant with the PFEs mesophyll leaf size class, lateral leaf inclination, dorsiventral photosynthetic surface connected to a phanerophytic life form would constitute the PFT me-la-do-ph. A multivariate distance measure (a self-standardizing Gower metric) is used to quantify divergence amongst PFTs and also amongst PFT assemblages (Gillison and Carpenter 1997; Gillison 2002). For each sample, PFT richness can be expressed either as the number of species recorded per PFT (species weighted) or as the total number of PFTs recorded independently of species (unique). Similarly, PFEs can be measured summatively either by unique PFTs (PFT-weighted PFEs), or species for each sample plot. We used public domain VegClass $\subseteq$ software (Gillison 2002) to compile and tabulate data. In the field each $40 \times 5 \mathrm{~m}$ transect comprised eight contiguous, $5 \times 5 \mathrm{~m}$ quadrats from which the data were analysed, again using VegClass $\subseteq$, to construct species:area and PFT:area curves as a measure of local sampling efficiency (Gillison 2006; Tables S4, S5, S20, Online Resources). Vegetation structure comprised mean canopy height and projective cover, percent basal area for all woody plants using a Bitterlich method, Domin scale cover for woody plants and bryophytes, and mean furcation index (Gillison 2002, 2006). In addition, VegClass $(\mathcal{C}$ was used to generate a plant functional complexity (PFC) index (Appendix S1, Online Resources). The PFC value is estimated as the total length of a minimum spanning tree distance passing through all PFT combinations (Gillison and Carpenter 1997; Gillison 2000). The PFC index provides a comparative measure of PFT variability, for example where two or more plots have the same PFT richness but differ in composition.

\section{Vertebrate fauna}

Ornithologists (two persons per site visit) identified birds by calls, referenced to standard audio discs, during 90 min observations at dawn and dusk. Capture by mist netting was also undertaken during daylight hours. Small mammals were sampled in baited traps, larger mammals by direct observations (similar to those for birds) and from fresh droppings. 
Observations were made within an approximate $200 \mathrm{~m}$ radius of each base transect (Tables S8-S10, Online Resources). Full details of methods and critiques are given in Gillison (2000).

\section{Invertebrate fauna (termites)}

Methods used to assess termites differed somewhat between the two regions, although the area sampled $\left(200 \mathrm{~m}^{2}\right)$ was the same in both cases. In Sumatra, termites were extracted from mounds, plant litter and soil along a $100 \mathrm{~m}$ line transect of $2 \mathrm{~m}$ width adjacent to the vegetation transect, with one person-hour of sampling effort for each $5 \mathrm{~m}$ of the transect (Swift and Bignell 2001; Jones et al. 2003). In Mato Grosso, termites were sampled intensively mainly aboveground by two people for $2 \mathrm{~h}$ inside the vegetation transects (base transects). Termite diversity was recorded as counts of species per transect and termite abundance as the number of encounters with all species per transect, including repeat encounters within a species (Appendix S1, Tables S11, S12, Online Resources). Full details are given in Jones et al. (2003) and Gillison et al. (2003).

\section{Soil}

Soil and vegetation samples were co-located for all sites in each region. Soils were sampled within the base transect and subjected to routine laboratory analyses for a standard suite of parameters including texture, bulk density, $\mathrm{pH}$, conductivity, $\mathrm{C}, \mathrm{N}, \mathrm{P}, \mathrm{S}$, exchangeable cations ( $\mathrm{Na}, \mathrm{K}, \mathrm{Ca}, \mathrm{Mg}$ ), other mineral elements (Al, Mn, B, Zn, Cu, Fe) (Appendix S1, Tables S15-S18, Online Resources; see also Gillison 2000). Because most important soil information associated with plant and animal distribution is contained in the surface horizons, we report correlative analyses between soil data from 0 to $10 \mathrm{~cm}$ depth, and biota.

\section{Data analysis}

We examined whether simple measures of vegetation structure, and structural and functional trait diversity were meaningfully correlated with plant and animal species richness. The purpose was to identify straightforward and promising relationships that apply to diverse tropical communities, rather than single examples where one biological feature predicts another. PFT data were analysed in two forms: PFT counts per transect weighted by the number of species occurring in each PFT, and PFT counts recorded without reference to species (unique PFTs). In addition to whole PFTs, we disaggregated both PFT forms into their component elements (PFEs) to permit correlation of individual functional traits with individual species, species diversity and soil properties including carbon. Plants, birds, mammals and termites were assessed at individual species level and as assemblages. To find easily applicable indicators we focused on univariate linear relationships, as non-linear and multivariate relationships are more difficult to calibrate and apply, although we do not exclude the possibility that they occur (see Appendix S3, Online Resources). In a few cases we have reported quadratic univariate relationships that appear striking. Pearson productmoment analysis was used to generate a linear correlation matrix for all recorded variables for both regions separately and combined. Correlation was tabulated as the coefficient $r$ and tested for significance via the Fisher- $z$ transformation using Minitab 14.2 (Gillison 2005).

Linear regression between pairs of variables was also carried out by the ordinary least squares method (1,307 regressions). In a few selected cases these are illustrated (Figs. 1, 2 ), with the equation of the fitted line and the adjusted coefficient of determination, RSq. In 
Fig. 1 Variations in correlative responses between animal taxonomic richness and plant-based indicators illustrated by birds and termites. The differences reflect regional ecosystem characteristics. In Brazil a savanna-like sites are low in litter but rich in specialist plants that support bird life. In Sumatra b low litter accumulation is associated with species-poor, highly modified land-use types such as degraded Imperata grassland, Cassava (Manihot) food gardens and rubber plantations. The termite response to litter depth c, d is linear in the relatively homogeneous lowland plains of Sumatra and curvilinear in the more environmentally heterogeneous Mato Grosso. A similar response by termites to the plant spp.:PFTs ratio e, f also indicates a common trend in termite diversity response to vegetation disturbance. PFT plant functional type. Sumatran results adapted from Gillison (2000)

160 cases of significant and 14 close-to-significant regression slopes, pairs of variables are tabulated with the $t$ statistic (i.e. the slope of the line divided by its standard error) and its associated significance (Tables S21, S22, Online Resources).

Empirical false discovery rates (Soriç 1989) were estimated for the entire set of reported regressions by the method of Brewer and Hayes (2011) and are summarized in Table S23 (and see Appendix S3, both in Online Resources). Multiple regressions were not undertaken, as for practical purposes the aim was to test for single indicators. Because the study is exploratory in nature but also focuses on finding relationships that hold in both (Asian) Palaeotropical and Neotropical landscapes, the specific probability values associated with each statistical relationship being characterized are given-this reduces the need for additional assumptions and allows the results to be transparent and available for future meta-analyses (see Stewart-Oaten 1995 for a more detailed justification of such approaches). Significant correlations are those with a probability value of 0.0025 or less, rather than of 0.05 , so as to reflect the false discovery rate associated with these sequential tests. The theory leading to this adjustment is fully set out by Brewer and Hayes (2011) and discussed in the context of our analyses in Appendix S3 and the footnotes to Tables S21 and S22, all in Online Resources. However, some correlations resulting in $0.05>P>0.0025$ are nevertheless reported and discussed. To reduce confusion in these cases, where appropriate a note added in parenthesis restates the statistical inference. The possibility of unimodal responses was examined by visual scan, but not otherwise tested.

\section{Results}

\section{Biodiversity summary}

In 32 transects in Mato Grosso 542 plant species (1,241 records) and 369 unique (869 species-weighted) PFTs were recorded. In 16 representative subsets of these transects we documented 73 species of vertebrate fauna (17 mammals, 56 birds) and 64 termite species in 11 transect subsets. In Sumatra 16 transects yielded 562 plant species (980 records) and 216 unique (459 species-weighted) PFTs, together with 194 species of vertebrate fauna (31 mammals, 163 birds) in 15 representative transect subsets and 53 termite species in seven representative transect subsets (Tables S4-S12, Online Resources).

\section{Predictors}

Plant species richness (number of species in a transect) was best predicted by unique PFT richness, then vegetation structure, cover-abundance of bryophytes, mean canopy height and woody basal area (Table 1). In both regions local plant species richness was also 

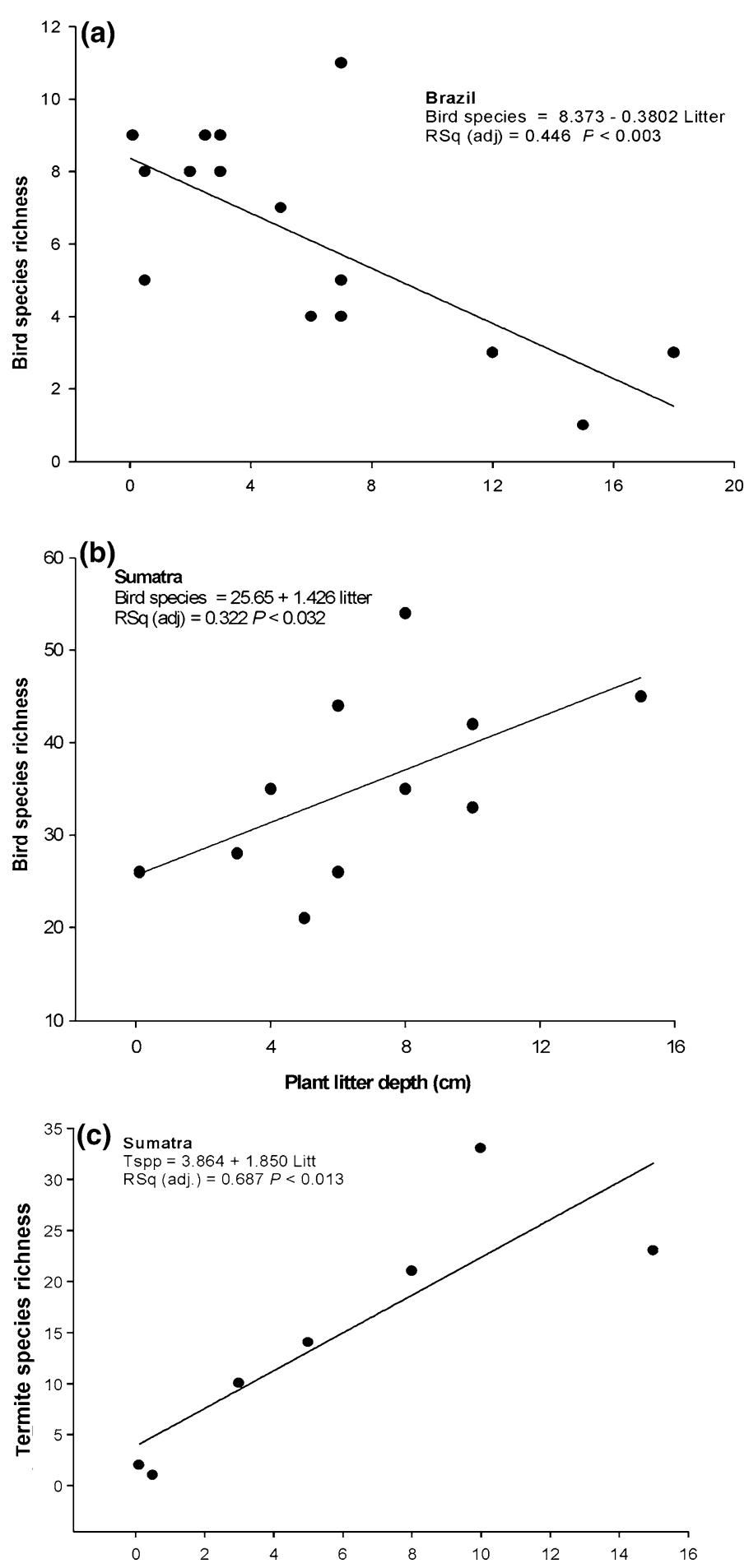


\section{(d)}
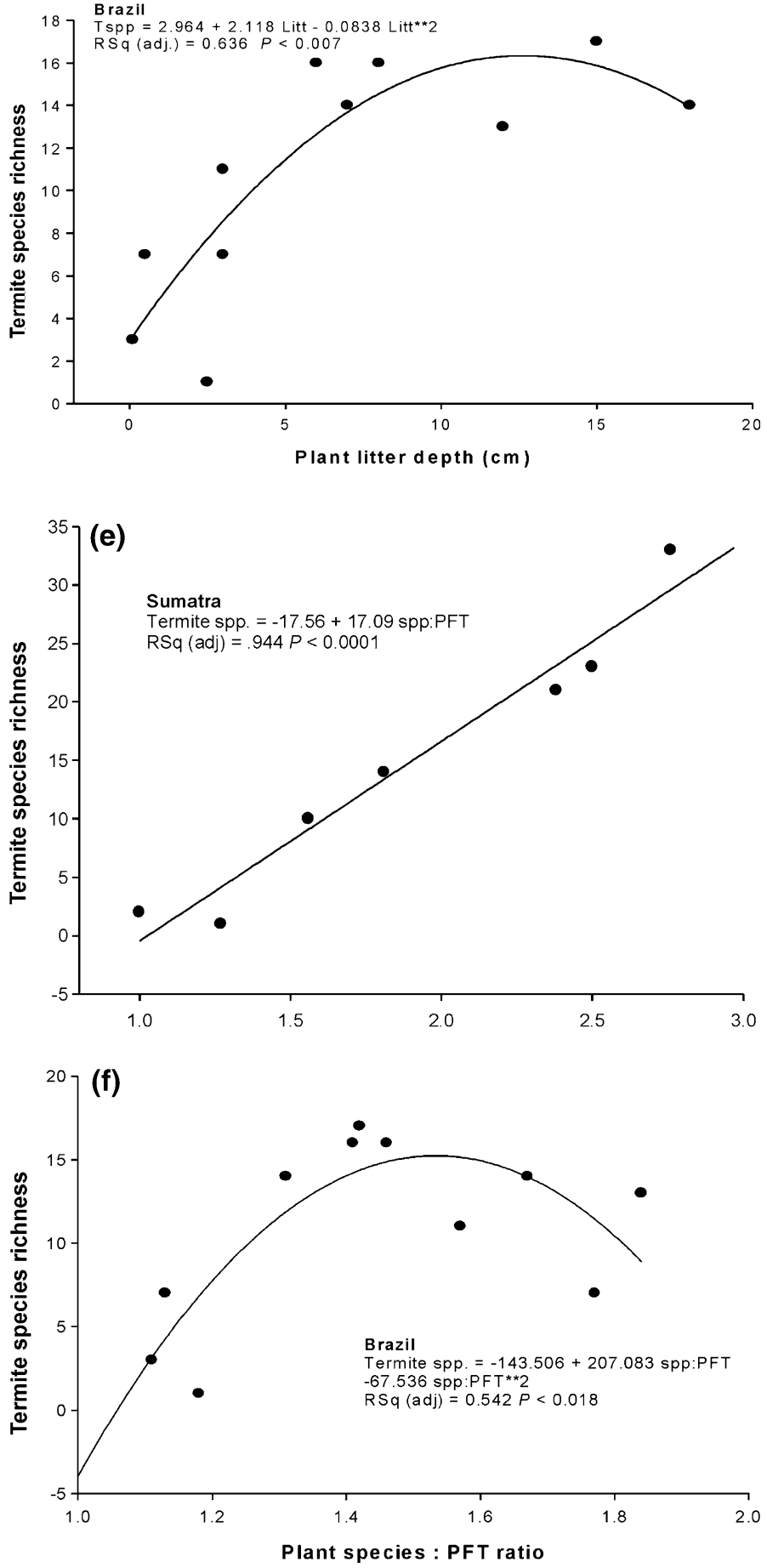

Fig. 1 continued 
correlated with 16 unique PFT-weighted PFEs (Table 2). Of these, 8 were strong $(P<0.0001)$ and consistent between the two regions and seven close to significant $(P<0.015)$ though with some variation between Brazil and Sumatra. Some features of vegetation structure, including PFT and plant species diversity, the ratio of plant species diversity to PFT diversity (spp.:PFTs), plant litter depth, mean canopy height, woody basal area, canopy cover, percentage of woody plants and cover-abundance of bryophytes also predicted animal species richness, though somewhat less strongly, with the exception of woody basal area in Sumatra, which was strongly correlated with termite species richness $(P=0.001)$. Termite abundance (i.e. encounters per transect) was linked with litter depth in both regions $(P \approx 0.016$, though interpreted as not significant following correction for false discovery rates) but less strongly with plant species diversity $(P \approx 0.042)$. Figure 1a-d illustrates differing regional trend lines for bird species richness against litter depth (a, b) and termite species richness, also against litter depth (c, d). Divergent responses between plant litter depth and bird and termite species diversities, respectively, may reflect regional differences in habitat structure, vegetation type and biogeography. The Sumatran sites that are modified agroforests or plantations have no natural savanna or parkland nearby, and hence probably a reduced pool of organisms from which to occupy new niches created in the process. In Brazil, increased species turnover would be expected at forest margins (and hence high $\beta$-diversity over the gradsect as a whole). Many unique PFT-weighted PFEs were significantly correlated with faunal diversity, but speciesweighted PFEs were more efficient predictors overall (Table 2; Fig. 1e, f, main text; Tables S13, S14, Online Resources).

Combining Brazilian and Sumatran data increased the number of significant generic predictors and the statistical significance of correlations between plant-based variables and species diversity in faunal groups (Tables 3,4). Correlations of richness between faunal groups also improved substantially when Brazilian and Sumatran data were combined: bird and mammal species diversity $(r=0.676, P=0.0001$, highly significant), mammal and termite species diversity $(r=0.550, P \approx 0.027$, though not significant following correction for false discovery rates) and mammal species diversity and termite abundance ( $r=0.710, P \approx 0.002$, significant) [data not tabulated].

Plant species diversity was closely correlated with PFE diversity (Table 3). Although more than one species can occur within a single PFT and vice versa, species richness and PFT richness usually tend to be highly correlated. That their statistical relationship can and does vary with environment is indicated by a significant difference in regression slopes between the two regions (Fig. 2). Variation in within-sample diversity along land use intensity gradients therefore appears to be distinct between Brazil and Sumatra (see Appendix S3, Online Resources).

\section{Replicable patterns}

Regionally distinguishable relationships were found between some soil textural properties and biota (Tables S15, S16; Online Resources). Mato Grosso soil properties were weakly correlated with plant and animal species diversities whereas Sumatran soil properties were strongly correlated with plant species diversity and mammals, and to a lesser degree birds and termites (Tables S17, S18, Online Resources). However, no single soil variable was significantly correlated with fauna in either region, and only one (Al saturation) with plants. In contrast, plant adaptive features represented by PFEs (functional traits) exhibited significant and consistent cross-regional responses to soil properties and in both regions 


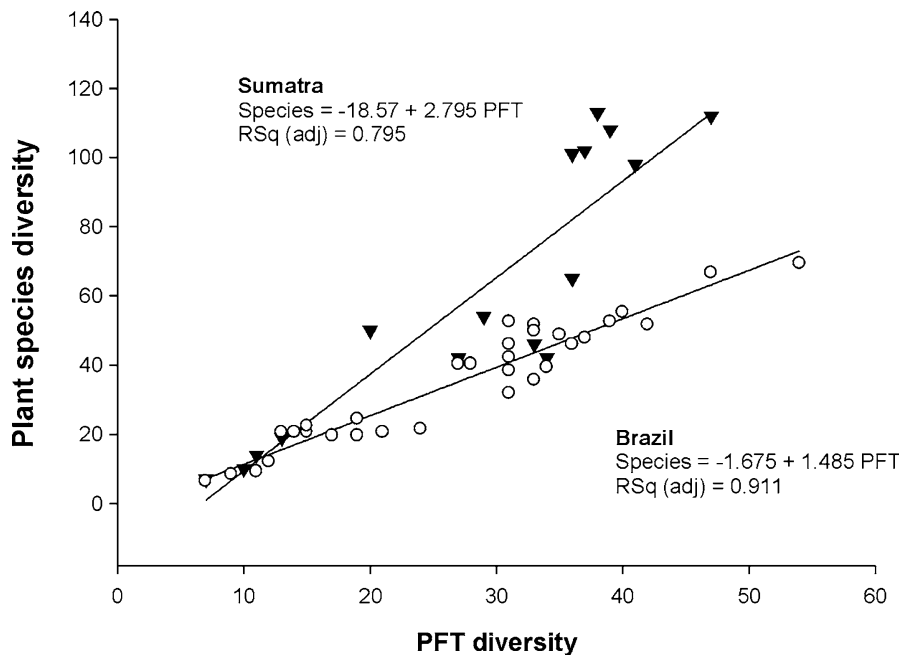

Fig. 2 The relationship between vascular plant species richness and plant functional type (PFT) diversity in Brazilian and Sumatran sites. Significant differences in the patterns of scatter for Sumatra (triangles) and Brazil (circles) reflect regional coefficients in species to PFT ratios along land use intensity gradients. While the original ordinary least squares regressions are presented here for illustrative purposes, for comparative analysis the regressions are required to pass through the origin. The Satterthwaite approximation (see Appendix S3, Online Resources) was used to test for a significant difference between the two resulting regression slopes. Assuming extreme heteroskedasticity, the significance level was $P<0.01$. A more conservative heteroskedastic model, also passing through the origin, would have resulted in a higher level of statistical significance. PFT plant functional type. Adapted from Gillison (2013)

Table 1 Correlative values (Pearson product-moment correlation) between taxonomic target groups and candidate plant-based indicators (vegetation structure) common to both Brazil and Sumatra, showing separate regional data

\begin{tabular}{|c|c|c|c|c|c|}
\hline \multirow[t]{2}{*}{ Target group } & \multirow[t]{2}{*}{ Indicator } & \multicolumn{2}{|l|}{ Brazil } & \multicolumn{2}{|c|}{ Sumatra } \\
\hline & & $r$ & $P$ & $r$ & $P$ \\
\hline \multirow[t]{6}{*}{ Plant species } & Unique PFT diversity & 0.956 & 0.0001 & 0.900 & 0.0001 \\
\hline & Bryophytes & 0.642 & 0.0001 & 0.716 & 0.002 \\
\hline & Woody plants $<2 \mathrm{~m}$ tall & 0.688 & 0.0001 & 0.614 & 0.011 \\
\hline & Mean canopy height & 0.558 & 0.001 & 0.894 & 0.0001 \\
\hline & Basal area all woody plants & 0.499 & 0.004 & 0.925 & 0.0001 \\
\hline & Litter depth & 0.359 & 0.043 & 0.674 & 0.004 \\
\hline Bird species & Litter depth & -0.695 & 0.003 & 0.619 & 0.032 \\
\hline \multirow[t]{2}{*}{ Mammal species } & Basal area of woody plants & 0.613 & 0.012 & 0.617 & 0.014 \\
\hline & Mean canopy height & 0.597 & 0.015 & 0.615 & 0.015 \\
\hline \multirow[t]{2}{*}{ Termite species } & Litter depth & 0.710 & 0.014 & 0.847 & 0.016 \\
\hline & Basal area all woody plants & 0.614 & 0.045 & 0.955 & 0.001 \\
\hline \multirow[t]{2}{*}{ Termite abundance } & Litter depth & 0.769 & 0.016 & 0.907 & 0.005 \\
\hline & Plant species diversity & 0.620 & 0.042 & 0.847 & 0.016 \\
\hline
\end{tabular}

Excluding PFEs (see Table 2). Sample sizes are, respectively, the number of sites sampled for each target group, listed in "Methods" section

$P F T$ plant functional type; $P F E$ plant functional element 
Table 2 Correlative values (Pearson product-moment correlation) between taxonomic target groups and candidate plant functional element (PFE) traits common to both Brazil and Sumatra, showing separate regional data

\begin{tabular}{|c|c|c|c|c|c|}
\hline \multirow[t]{2}{*}{ Target group } & \multirow[t]{2}{*}{ Indicator } & \multicolumn{2}{|l|}{ Brazil } & \multicolumn{2}{|c|}{ Sumatra } \\
\hline & & $r$ & $P$ & $r$ & $P$ \\
\hline \multirow[t]{16}{*}{ Plant species } & Dorsiventral ls. $(\text { do })^{\mathrm{b}}$ & 0.958 & 0.0001 & 0.900 & 0.0001 \\
\hline & Mesophyll (me $)^{\mathrm{b}}$ & 0.818 & 0.0001 & 0.837 & 0.0001 \\
\hline & Phanerophyte $(\mathrm{ph})^{\mathrm{b}}$ & 0.816 & 0.0001 & 0.954 & 0.0001 \\
\hline & Lateral incl. 1s.(la $)^{\mathrm{b}}$ & 0.789 & 0.0001 & 0.921 & 0.0001 \\
\hline & Platyphyll (pl) ${ }^{\mathrm{b}}$ & 0.721 & 0.0001 & 0.840 & 0.0001 \\
\hline & Green $\mathrm{p} / \mathrm{s}$ stem $(\mathrm{ct})^{\mathrm{b}}$ & 0.687 & 0.0001 & 0.908 & 0.0001 \\
\hline & Composite incl. 1s. (co) $)^{\mathrm{b}}$ & 0.507 & 0.003 & 0.838 & 0.0001 \\
\hline & Succulent $(\mathrm{su})^{\mathrm{b}}$ & 0.488 & 0.005 & 0.826 & 0.0001 \\
\hline & Rosulate 1s.(ro $)^{\mathrm{b}}$ & 0.463 & 0.008 & 0.833 & 0.0001 \\
\hline & Lianoid life form $(\mathrm{li})^{\mathrm{b}}$ & 0.822 & 0.0001 & 0.744 & 0.001 \\
\hline & Graminoid $(\mathrm{pv})^{\mathrm{b}}$ & 0.578 & 0.001 & 0.734 & 0.001 \\
\hline & Notophyll (no) ${ }^{\mathrm{b}}$ & 0.815 & 0.0001 & 0.712 & 0.002 \\
\hline & Epiphyte (ep) $)^{\mathrm{b}}$ & 0.465 & 0.007 & 0.707 & 0.002 \\
\hline & Adventitious roots $(\mathrm{ad})^{\mathrm{b}}$ & 0.722 & 0.0001 & 0.593 & 0.015 \\
\hline & Microphyll (mi) ${ }^{\mathrm{b}}$ & 0.399 & 0.024 & 0.503 & 0.047 \\
\hline & Hemicryptophyte $(\mathrm{hc})^{\mathrm{b}}$ & 0.668 & 0.0001 & 0.500 & 0.048 \\
\hline \multirow[t]{5}{*}{ Mammal species } & Succulent leaves $(\mathrm{su})^{\mathrm{a}}$ & 0.491 & 0.053 & 0.784 & 0.001 \\
\hline & Filicoid leaves (fi) ${ }^{\mathrm{a}}$ & 0.625 & 0.010 & 0.569 & 0.027 \\
\hline & Filicoid leaves (fi) ${ }^{\mathrm{b}}$ & 0.621 & 0.010 & 0.564 & 0.029 \\
\hline & Lateral incl. leaves $(\text { la })^{\mathrm{b}}$ & 0.517 & 0.040 & 0.898 & 0.0001 \\
\hline & Adventitious roots $(\mathrm{ad})^{\mathrm{b}}$ & 0.616 & 0.011 & 0.537 & 0.039 \\
\hline Termite species & Lateral incl. leaves (la) ${ }^{\mathrm{a}}$ & 0.669 & 0.024 & 0.838 & 0.019 \\
\hline \multirow[t]{4}{*}{ Termite abundance } & Lateral incl. leaves $(1 a)^{a}$ & 0.721 & 0.012 & 0.839 & 0.018 \\
\hline & Lateral incl. leaves $(\mathrm{la})^{\mathrm{b}}$ & 0.606 & 0.048 & 0.763 & 0.046 \\
\hline & Dorsiventral leaves (do) $^{\mathrm{a}}$ & 0.623 & 0.040 & 0.839 & 0.018 \\
\hline & Mesophyll size leaves (me $)^{\mathrm{a}}$ & 0.735 & 0.010 & 0.765 & 0.045 \\
\hline
\end{tabular}

Sample sizes are, respectively, the number of sites sampled for each target group (see "Methods" section)

${ }^{\text {a }}$ Species-weighted PFTs

${ }^{\mathrm{b}}$ Unique PFT-weighted

species-weighted PFEs were correlated with $\mathrm{pH}, \mathrm{CEC}, \mathrm{H}, \mathrm{K}, \mathrm{P}$ and texture (\% sand, silt, clay). PFEs which were components of unique PFTs exhibited highly significant correlations with soil bulk density, and \% sand, silt, clay, as well as CEC and organic carbon (e.g. Table S19, Online Resources).

Biodiversity indicators and carbon sequestration

For logistical reasons carbon estimates were recorded only for the Sumatran baseline where both total and aboveground carbon correlated strongly with vegetation structure, 
plant species and PFT diversity and the spp.:PFTs ratio (Table S19, Online Resources). A significant statistical relationship between plant species composition and either total or aboveground carbon was not detected. However, a borderline correlation between PFC and aboveground carbon $(r=0.603, P \approx 0.013)$ and total carbon $(r=0.640, P \approx 0.008)$ suggests logging and forest conversion affect PFTs and carbon stocks in parallel, but differentially, as carbon stocks are dominated by the largest trees. Termite species diversity and abundance were linked with aboveground carbon (termite diversity $r=0.890$, $P \approx 0.007$; termite abundance $r=0.898, P \approx 0.006$ ) and total carbon (diversity $r=0.789, P \approx 0.035$; abundance $r=0.802, P \approx 0.030$ ).

\section{Discussion}

The results provide evidence that the use of readily observable plant functional morphologies and vegetation structure is a practical basis for comparative ecological studies of complex terrestrial environments, both within and between regions. The different strengths of relationships may reflect both complex multi-causality and differences in effective sampling effort relative to inherent variability of the parameters assessed.

The gradsect approach proved to be efficient in sampling major axes of environmental variability. Many biodiversity surveys either employ unstructured sampling or else randomized or purely systematic (usually grid-based) approaches. While these may satisfy statistical sampling theory, they are inefficient and costly to apply in complex habitats, or depending on the size of the window employed are inconsistent with the spatial scale and patch dimensions of tropical landscapes (Huising et al. 2008). Where the aim is to detect maximum diversity or richness among species and functional groups, habitat variation is more efficiently sampled through gradient-based, non-random approaches, for which theory and practice are now well established (Gillison and Brewer 1985; Wessels et al. 1998; Jones and Eggleton 2000; Gillison 2002; Knollová et al. 2005; Parker et al. 2011).

The areas sampled in our study, both in Sumatra and Brazil included definitive areas of several hectares of intermediate disturbance, notably 'Jungle Rubber' in Sumatra, and 'Capoeira' in Brazil. The questions that arise are whether increases in alpha diversity in these cases should be consistent with the intermediate disturbance hypothesis, and whether the relatively small samples represented by a $40 \times 5 \mathrm{~m}$ transect would be able to disentangle plant structural traits representative of forest community types from those occurring in their gap succession. The sampling approach using $40 \times 5 \mathrm{~m}$ transects showed high peaks of alpha diversity consistent with that hypothesis and with other studies in IndoMalesia using the same methodology to address ridge lines, soil catenary sequences, riparian strips and forest margins (Gillison and Liswanti 2004; Gillison et al. 2004). This level of detection is frequently beyond the capacity of sampling strategies employing larger plot sizes (e.g. $50 \times 10 \mathrm{~m}$ and above). The relatively small plot size $(40 \times 5 \mathrm{~m})$ facilitates intensive recording of taxa and functional types and at the same time is logistically suited to additional sampling along environmental gradients and to reduction in observer fatigue.

Gillison (2013) has shown the plant functional approach (VegClass system) used here is highly sensitive not only to disturbance and modification but also to variation within 'primary' forest due to soil nutrient status (cf. Condit et al. 2013). The extent to which faunal groups might respond to such variations within the baseline transect is unknown, though given the relationship between vascular plants and faunal groups detected in the gradsects, some effects due to host plant specificity (for instance on herbivorous insects) might be expected. However, the present study focuses on modified forest landscapes 
Table 3 Correlative values (Pearson product-moment correlation) between taxonomic target groups and candidate plant-based indicators (vegetation structure) common to both Brazil and Sumatra, showing combined data

\begin{tabular}{|c|c|c|c|}
\hline \multirow[t]{2}{*}{ Target group } & \multirow[t]{2}{*}{ Indicator } & \multicolumn{2}{|c|}{ Brazil + Sumatra } \\
\hline & & $R$ & $P$ \\
\hline \multirow[t]{7}{*}{ Plant species } & Unique PFT diversity & 0.829 & 0.0001 \\
\hline & PFC & 0.703 & 0.0001 \\
\hline & Basal area all woody plants & 0.565 & 0.0001 \\
\hline & Mean canopy height & 0.558 & 0.0001 \\
\hline & Woody plants $<2 \mathrm{~m}$ tall cov/abd & 0.533 & 0.0001 \\
\hline & Bryophyte cover/abundance & 0.509 & 0.0001 \\
\hline & Litter depth $(\mathrm{cm})$ & 0.455 & 0.001 \\
\hline \multirow[t]{2}{*}{ Bird species } & Spp.:PFTs & 0.682 & 0.0001 \\
\hline & Plant species & 0.565 & 0.002 \\
\hline \multirow[t]{5}{*}{ Mammal species } & Plant species & 0.681 & 0.0001 \\
\hline & Spp.:PFTs & 0.598 & 0.0001 \\
\hline & Basal area of woody plants & 0.479 & 0.006 \\
\hline & Mean canopy height & 0.475 & 0.007 \\
\hline & Unique PFT diversity & 0.470 & 0.008 \\
\hline \multirow[t]{6}{*}{ Termite species } & Spp.:PFTs & 0.847 & 0.0001 \\
\hline & Plant species & 0.785 & 0.0001 \\
\hline & Litter depth & 0.669 & 0.002 \\
\hline & Furcation index woody plants & -0.551 & 0.018 \\
\hline & Basal area all woody plants & 0.541 & 0.021 \\
\hline & Unique PFT diversity & 0.519 & 0.027 \\
\hline \multirow[t]{2}{*}{ Termite abundance } & Spp.:PFTs & 0.922 & 0.0001 \\
\hline & Plant species & 0.791 & 0.0001 \\
\hline \multirow[t]{2}{*}{ Total fauna species } & Spp.:PFTs & 0.816 & 0.0001 \\
\hline & Plant species & 0.727 & 0.002 \\
\hline
\end{tabular}

Excluding PFEs (see Table 4). Sample sizes are, respectively, the sum of sites sampled for each target group (see "Methods" section and Table 1A)

where biota are responding to multiple changes along disturbance gradients and differing patterns of modification (forest and non-forest). The study was not intended to examine how location and scale related influences-for example proximity to primary forests, size of habitat, and landscape connectivity - might be detected and understood.

Human-induced habitat modification has a major impact on biodiversity in both study areas (Sumatra and Mato Grosso). Although the literature is rich in methods for assessing disturbance and related land use intensity (Watt et al. 1998), unambiguous, quantitative units remain elusive (Jackson et al. 2012). The present study showed that subjectively determined land use intensity and disturbance gradients correspond closely with changes in plant species and PFT diversities. Pristine lowland forests supported more PFTs but also more plant species per PFT than secondary or more heavily disrupted forests, thus indicating higher levels of niche complementarity at the scale of our sample-units. As more ecological niches become available for different PFTs with increasing disturbance (here indicated mainly by changes in vegetation structure and aboveground carbon), this 
Table 4 Correlative values (Pearson product-moment correlation) between taxonomic target groups and candidate unique PFT-weighted PFE indicators common to both Brazil and Sumatra, showing combined data

\begin{tabular}{|c|c|c|c|}
\hline \multirow[t]{2}{*}{ Target group } & \multirow[t]{2}{*}{ Indicator } & \multicolumn{2}{|c|}{ Brazil + Sumatra } \\
\hline & & $r$ & $P$ \\
\hline \multirow[t]{18}{*}{ Plant species } & Phanerophyte (ph) & 0.885 & 0.0001 \\
\hline & Dorsiventral (do) & 0.833 & 0.0001 \\
\hline & Lateral incl. (la) & 0.804 & 0.0001 \\
\hline & Mesophyll (me) & 0.784 & 0.0001 \\
\hline & Notophyll (no) & 0.751 & 0.0001 \\
\hline & Photosynthetic stem (ct) & 0.719 & 0.0001 \\
\hline & Rosulate (ro) & 0.716 & 0.0001 \\
\hline & Lianoid (li) & 0.709 & 0.0001 \\
\hline & Succulent (su) & 0.634 & 0.0001 \\
\hline & Adventitious (ad) & 0.588 & 0.0001 \\
\hline & Graminoid (pv) & 0.571 & 0.0001 \\
\hline & Hemicryptophyte (hc) & 0.555 & 0.0001 \\
\hline & Filicoid (fi) & 0.536 & 0.0001 \\
\hline & Platyphyll (pl) & 0.475 & 0.001 \\
\hline & Epiphytic (ep) & 0.458 & 0.001 \\
\hline & Composite incl. (co) & 0.441 & 0.002 \\
\hline & Microphyll (mi) & 0.425 & 0.003 \\
\hline & Macrophyll (ma) & 0.291 & 0.045 \\
\hline \multirow[t]{4}{*}{ Bird species } & Rosulate (ro) & 0.480 & 0.010 \\
\hline & Chamaephyte (ch) & -0.475 & 0.011 \\
\hline & Phanerophyte (ph) & 0.414 & 0.029 \\
\hline & Lateral incl (la) & 0.378 & 0.047 \\
\hline \multirow[t]{14}{*}{ Mammal species } & Lateral incl. (la) & 0.707 & 0.0001 \\
\hline & Phanerophyte (ph) & 0.599 & 0.0001 \\
\hline & Filicoid (fi) & 0.591 & 0.0001 \\
\hline & Succulent (su) & 0.589 & 0.0001 \\
\hline & Notophyll (no) & 0.575 & 0.001 \\
\hline & Mesophyll (me) & 0.537 & 0.002 \\
\hline & Hemicryptophyte (hc) & 0.524 & 0.002 \\
\hline & Dorsiventral (do) & 0.471 & 0.008 \\
\hline & Adventitious & 0.458 & 0.010 \\
\hline & Rosulate (ro) & 0.457 & 0.010 \\
\hline & Lianoid (li) & 0.438 & 0.014 \\
\hline & Graminoid (pv) & 0.433 & 0.015 \\
\hline & Epiphytic (ep) & 0.430 & 0.016 \\
\hline & Pendulous incl. (pe) & -0.375 & 0.038 \\
\hline \multirow[t]{4}{*}{ Termite species } & Phanerophyte (ph) & 0.739 & 0.001 \\
\hline & Lateral incl. (la) & 0.632 & 0.005 \\
\hline & Mesophyll (me) & 0.594 & 0.009 \\
\hline & Notophyll (no) & 0.593 & 0.009 \\
\hline
\end{tabular}


Table 4 continued

\begin{tabular}{llcc}
\hline Target group & Indicator & \multicolumn{2}{l}{ Brazil + Sumatra } \\
\cline { 3 - 4 } & & $r$ & $P$ \\
\hline & Leptophyll (le) & -0.583 & 0.011 \\
& Dorsiventral (do) & 0.527 & 0.025 \\
& Rosulate (ro) & 0.525 & 0.025 \\
& Lianoid (li) & 0.494 & 0.037 \\
Termite abundance & Phanerophyte (ph) & 0.692 & 0.001 \\
& Mesophyll (me) & 0.597 & 0.009 \\
& Notophyll (no) & 0.552 & 0.018 \\
All fauna species & Lateral incl. (la) & 0.477 & 0.045 \\
& Phanerophyte (ph) & 0.646 & 0.009 \\
& Mesophyll (me) & 0.604 & 0.017 \\
& Lateral incl. (la) & 0.565 & 0.028 \\
& Filicoid (fi) & 0.539 & 0.038 \\
\hline
\end{tabular}

Sample sizes are, respectively, the sum of sites sampled for each target group (see "Methods" section). For other correlations with PFEs, see Table S14

a Species diversity of all joint occurrences of birds, mammals and termites per transect

ratio decreases until in freshly opened agricultural land or in extreme (e.g. degraded) conditions, the ratio approaches unity (Gillison 2002). In the present study, when regional data were combined, the spp.:PFTs ratio became the strongest overall predictor of faunal species diversity thus suggesting a generally consistent response to disturbance across all biota, though with some exceptions at intermediate disturbance levels (cf. Watt et al. 1998; Sheil and Burslem 2003), for example termite diversity in Brazil. Habitat disturbance (measured here as loss of phytomass-see Appendices S1 and S2, Online Resources) corresponded closely with decreasing spp.:PFTs ratio, supporting the use of the latter as an effective indicator of biodiversity where disturbance is a major driver of ecosystem performance.

Combining regional data resulted in an almost two-fold increase in the overall number of significant or near-significant generic indicators and a three-fold increase in numbers of indicators significant at the $P \leq 0.0001$ level, supporting the conclusion that such indicators may be applied with relative confidence in similar lowland tropical forested regions and with minimum effort. Unlike the traits used in our study, logistically demanding measurements of many functional traits, e.g. leaf mass per area, seed mass and seed output (Westoby et al. 2002; Cornelissen et al. 2003; Wright et al. 2004) are impractical for rapid survey in complex tropical forests. The results also suggest that readily-observable traits common to all terrestrial vegetation allow comparison where environments may be similar but where species differ (Gillison and Carpenter 1997). Further, it is shown that the construction of PFTs from PFEs facilitates complementary assessment of diversity in both species and functional types. Where limited sampling restricts statistical analyses, these may be improved by disaggregating PFTs into their generic PFE components. In our studies (Tables 2, 4) PFEs provided a supplementary subset of statistically significant biodiversity surrogates across a wide range of land cover types and spatial scales. Along 
the broader-scale environmental gradients in Mato Grosso, transects in structurally simple, savanna-related vegetation on an upland sandstone plateau (nutrient-poor, shallow soils) were richer in fauna than most structurally complex, lowland forest transects on deep, more fertile, well drained soils. Although the inclusion of the savanna-related outliers improved the sample range of species habitat, the coupling of species data from very different biomes may have reduced the effectiveness of simple univariate analyses. By comparison the smaller scale, but less physically heterogenous and more biodiverse Sumatran baseline produced more statistically robust biodiversity indicators.

Landscapes at tropical forest margins usually include a mosaic of habitats with and without trees where many so-called 'forest' biota range well beyond forest boundaries (Sanchez et al. 2005). Yet biodiversity-related surveys in tropical forest biomes typically rely on tree-based assessment (Dallmeier and Comiskey 1996). The omission of non-tree components of vegetation and non-forest habitat can exclude information critical for effective conservation planning and management. The present study provides scientific support for a logistically cost-effective assessment of forest biodiversity that includes all vascular plants. Although empirical evidence for plant response to soil variables such as $\mathrm{Al}^{3+}$ is difficult to establish because of variations in nutrient-cycling pathways, correlations between vegetation structure, plant functional features and soil physical properties (\% silt and sand) are readily interpretable, as these are soil parameters not influenced by vegetation (Table S15, Online Resources). As increasing silt content generally improves the supply of plant-available water during drier periods, a favourable soil texture may support higher plant productivity. Soil physical conditions, including litter depth, can be linked with faunal habitat. Plant litter is a food and habitat resource with important structural properties (measured here by depth) for termites and other invertebrate biota. Although litter depth frequently exhibits seasonal variation around its mean value (litter fall divided by mean residence time; Hairiah et al. 2006), relative differences along gradsects were consistent across all sites in both countries, as indeed elsewhere (see Fig. S2, Appendix S2, Online Resources).

A linkage between aboveground carbon, total organic carbon (standing vegetation, dead wood, litter and soil combined) and diversity in tree plant and termite species in Sumatra (Table S19, Online resources) suggests these variables should be examined further as candidate generic indicators. In both regions variations in soil texture and soil physical features such as bulk density exert important indirect effects on faunal diversity through their influence on plant growth and therefore on faunal habitats for which plants are the keystone providers. The same plant-based indicators can be used in other lowland forest types (Fig. S2, Appendix S2, Online Resources) although faunal baseline data are needed for proper evaluation. The lack of evidence for species-based indicators of other species reported here is consistent with findings in African tropical forests (Lawton et al. 1998). Where plant species identification is problematic, plant functional traits can be used as independent biodiversity surrogates. However, surrogacy is improved when functional trait and species data are combined. For this reason we suggest that the inclusion of adaptive PFTs and their component PFEs should be used to complement rather than replace speciesbased biodiversity assessment. The characterization of photosynthetic tissue, organs and life form in the PFEs together with vegetation structure (mean canopy height, percent canopy cover, basal area) contrasts with the more traditional and functionally restrictive (Raunkiaerean) plant life-forms and indicates greater potential for remote-sensing applications and monitoring forest condition at varying scales of spatial resolution (Asner et al. 2005). The emergence of the spp.:PFTs ratio as one of the more robust biodiversity 
surrogates, in addition to its potential use as an indicator in disturbed habitats, is a novel finding requiring further investigation.

Variable patterns of land use and differing management scales suggest that any single indicator, even the species diversity of a target taxon, will be of limited value to policy-makers and managers where multiple indicators are required, for example in the selection and gazetting of forest reserves (van Teeffelen et al. 2006). Alternatively, offering a set of simple indicators for efficient biodiversity assessment (cf. Hill and Hamer 2004) may be helpful for conservation decisions where comparative analyses of ecosystems are frustrated by incompatibilities in both scale and the biophysical environment. In cases such as the central Amazon basin, uncertainties surround the correct identification of many plant species (Gomes et al. 2013). Such challenges prevent stakeholders, who are otherwise willing, from investing in practical conservation evaluations and management (Meijaard and Sheil 2012). The present study shows that, based on a detailed analysis of the relationship between plant taxa and plant functional and structural types there is a scientifically defensible alternative when there are difficulties in identifying plant or other taxa. One of the central issues defining the utility of biodiversity indicators is their application across different biogeographic scales. Here we have shown that the indicators we detected at local regional scale also apply across widely separate biogeographic zones. Recent data also demonstrate that at global scale the plant functional and structural types used in the present study exhibit close relationships with climate, thus lending weight to their potential application across biomes (Gillison 2013).

Acknowledgments We acknowledge the logistical support provided by Instituto Pró-Natura and UNDP/ Brasília, the State Environmental Foundation of Mato Grosso, the Rohden Lignea Timber Company in Juruena, the Peugeot/ONF/IPN Carbon Sequestration Project in Cotriguaçu and the Municipal Secretariat of Agriculture in Castanheira. The Research and Development Center for Biology of the Indonesian Institute of Sciences (LIPI) provided botanical and zoological facilities through the Herbarium Bogoriense and the Museum Zoologicum Bogoriense (A. Budiman). In Brazil, herbarium and zoological facilities were provided by the Instituto de Biociências Universidade Federal de Mato Grosso, Cuiabá and Departamento de Zoologia, Universidade de Brasília. We thank N. Liswanti, J.J. Afriastini, I. Arief-Rachman, R.C. de Arruda, M. Boer, E. Carvelho, R. Carvelho, V. Kleber, L.A. Neto, L.A.Y. Nunes, M.C. de Oliveira, C.A.M. Passos, E. Permana, A. Rangel, C.H.N. Rohmar, L.F.U. dos Santos, E.M. Schuster, L. Sell, M. Tomazi, A.M. Vilela and U.R. Wasrin for technical assistance and advice. T.H. Booth, D. P. Faith and J.E. Richey kindly commented on the manuscript.

Open Access This article is distributed under the terms of the Creative Commons Attribution License which permits any use, distribution, and reproduction in any medium, provided the original author(s) and the source are credited.

\section{References}

Anderson JM, Ingram JSI (eds) (1993) Tropical soil biology and fertility: a handbook of methods, 2 nd edn. CAB International, Wallingford

Asner GP, Knox RG, Green RO, Ungar SG (2005) The Flora mission for ecosystem composition, disturbance and productivity. Mission concept for the national academy of sciences decadal study. Carnegie Institute of Washington, Stanford, p 15. http://pages.csam.montclair.edu/ chopping/rs/FLORA_ NRCDecadalSurvey_2005.pdf. Accessed 6 May 2012

Billeter R, Liira J, Bailey D, Bugter R, Arens P, Augnestein I, Aviron S, Baudry J, Bukacek R, Burel F, Cerny M, De Blust G, De Cock R, Diekötter F, Dietz H, Dirksen J, Dormann C, Durka W, Frenzel M, Hamersky R, Hendrickx F, Herzog F, Klotz S, Koolstra B, Lausch A, Le Cour D, Maelfait JP, Opdam P, Roubalova M, Schermann A, Schmidt T, Schweiger O, Smulders MJM, Speelmans M, Simova P, Verboom J, van Wingerden WKRE, Zobel M, Edwards PJ (2008) Indicators for biodiversity in agricultural landscapes: a pan-European study. J Appl Ecol 45:141-150 
Brewer KRW, Hayes D (2011) Understanding and using Fisher's $p$. Part 1: countering the $p$-statistic fallacy. Math Sci 36:117-125

Bunker DE, De Clerck F, Bradford JC, Colwell RK, Perfecto I, Phillips OL, Sankaran M, Naeem S (2005) Species loss and aboveground carbon storage in a tropical forest. Science 310:1029-1031

Chazdon RL, Peres CA, Dent D, Sheil D, Lugo AE, Lamb D, Stork NE, Miller S (2009) The potential for species conservation in tropical secondary forests. Conserv Biol 23:1406-1417

Condit R, Engelbrecht BMJ, Pino D, Pérez R, Turner BL (2013) Species distributions in response to individual soil nutrients and seasonal drought across a community of tropical trees. Proc Natl Acad Sci USA 110:5064-5068

Cornelissen JHC, Lavorel S, Garnier E, Diaz S, Buchmann N, Gurvich DE, Reich PB, ter Steege H, Morgan HD, van der Heijden MGA, Pausas JG, Poorter H (2003) A handbook of protocols for standardised and easy measurement of plant functional traits worldwide. Aust J Bot 51:335-380

Dallmeier F, Comiskey JA (1996) From the forest to the user: a methodology update. In: Wilson D, Sandoval A (eds) The biodiversity of southeastern Peru. Smithsonian Institution Press, Washington, DC, pp 41-56

Delbaere B (2002) Biodiversity indicators and monitoring. European Centre for Nature Conservation, Tilburg

Duckworth JC, Kent M, Ramsay PM (2000) Plant functional types: an alternative to taxonomic plant community description in biogeography? Progr Phys Geogr 24:515-542

Dudley N, Baldock D, Nasi R, Stolton S (2005) Measuring biodiversity and sustainable management in forests and agricultural landscapes. Philos Trans R Soc B 360:457-470

Dufrêne M, Legendre P (1997) Species assemblages and indicator species: the need for a flexible asymmetrical approach. Ecol Monogr 67:345-366

Duraiappah AK, Naeem S (2005) Ecosystems and human well-being: biodiversity synthesis. A report of the millennium ecosystem assessment. World Resources Institute, Washington DC

Eggleton P, Bignell DE, Sands WA, Waite B, Wood TG, Lawton JH (1995) The species richness of termites (Isoptera) under differing levels of forest disturbance in the Mbalmayo Forest Reserve, Southern Cameroon. J Trop Ecol 11:85-98

European Academies' Science Advisory Council (ESAC) (2004) A users' guide to biodiversity indicators. http://www.easac.eu/fileadmin/PDF_s/reports_statements/A.pdf. Accessed 10 May 2012

Folke C, Holling CS, Perrings C (1996) Biological diversity, ecosystems and the human scale. Ecol Appl $16: 1018-1024$

Gillison AN (2000) (ed) Above-ground biodiversity assessment working group summary report 1996-99. Impact of different land uses on biodiversity. Alternatives to slash and burn project. ICRAF, Nairobi, Kenya. http://www.asb.cgiar.org/PDFwebdocs/ASBBiodiversityReport.pdf. Accessed 6 May 2012

Gillison AN (2002) A generic, computer-assisted method for rapid vegetation classification and survey: tropical and temperate case studies. Conserv Ecol 6:3. http://www.consecol.org/vol6/iss2/art3. Accessed 6 May 2012

Gillison AN (2005) The potential role of above-ground biodiversity indicators in assessing best-bet alternatives to slash-and-burn. In: Palm CA, Vosti SA, Sanchez PA, Ericksen PJ (eds) Slash-and-burn agriculture, the search for alternatives. Columbia University Press, New York, pp 83-118

Gillison AN (2006) A field manual for rapid vegetation classification and survey for general purposes. Center for International Forestry Research, Jakarta

Gillison AN (2013) Plant functional types and traits at the community, ecosystem and world level. In: Van der Maarel E, Franklin J (eds) Vegetation ecology, 2nd edn. Wiley, Chichester, pp 347-386

Gillison A N, Liswanti N, Budidarsono S, van Noordwijk M, Tomich TP (2004) Impact of cropping methods on biodiversity in coffee agroecosystems in Sumatra, Indonesia. Ecol Soc 9:7. http://www.ecologyand society.org/vol9/iss2/art7. Accessed 18 May 2013

Gillison AN, Brewer KRW (1985) The use of gradient directed transects or gradsects in natural resource surveys. J Environ Manag 20:103-127

Gillison AN, Carpenter G (1997) A plant functional attribute set and grammar for dynamic vegetation description and analysis. Funct Ecol 11:775-783

Gillison AN, Liswanti N (2004) Assessing biodiversity at landscape level: the importance of environmental context. In: Tomich TP, van Noordwijk M, Thomas DE (eds) Environmental services and land-use change: bridging the gap between policy and research in Southeast Asia. Agric Ecosyst Environ 104:75-86

Gillison AN, Jones DT, Susilo FX, Bignell DE (2003) Vegetation indicates diversity of soil macroinvertebrates: a case study with termites along a land-use intensification gradient in lowland Sumatra. Org Divers Evol 3:111-126 
Global Environmental Facility (2000) Addendum to work program submitted for council approval. Project proposal A-2a, Brazil: promoting biodiversity conservation and sustainable use in the frontier forest of Northwestern Mato Grosso. GEF/C.15/3/Add 1. Washington, DC

Gomes ACS, Andrade A, Barreto-Silva JS, Brenes-Arguedas T, López DC, de Freitas CC, Lang C, de Oliveira AA, Pérez AJ, Perez R, da Silva JB, Silveira AMF, Vaz MC, Vendrami J, Vicentini A (2013) Local plant species delimitation in a highly diverse Amazonian forest: do we all see the same species? J Veg Sci 24:70-79

Gregory RD, Strien A, van Vorisek P, Meyling AWG, Noble DG, Foppen RPB, Gibbons DW (2005) Developing indicators for European birds. Philos Trans R Soc Lond B 360:269-288

Hairiah K, Sulistyani H, Suprayogo D, Purnomosidhi PW, Widodo RH, Van Noordwijk M (2006) Litter layer residence time in forest and coffee agroforestry systems in Sumberjaya, West Lampung. For Ecol Manag 224:45-57

Hill JK, Hamer KC (2004) Determining impacts of habitat modification on diversity of tropical forest fauna: the importance of spatial scale. J Appl Ecol 41:744-754

Howard P, Davenport T, Kigeny F (1997) Planning conservation areas in Uganda's natural forests. Oryx 31:253-262

Huising EJ, Coe R, Cares JE, Louzada JN, Zanetti R, Moreira FMS, Susilo F-X, Konaté S, Van Noordwijk M, Huang SP (2008) Sampling strategy and design to evaluate below-ground biodiversity. In: Huising EJ, Moreira FMS, Bignell DE (eds) Handbook of tropical soil biology. Earthscan, London, pp 17-42

Jackson LE, Pulleman MM, Brussaard L, Bawa KS, Brown G, Cardoso IM, De Ruiter P, García-Barrios L, Hollander AD, Lavelle P, Ouédraogo E, Pascual U, Setty S, Smukler SM, Tscharntke T, van Noordwijk M (2012) Social-ecological and regional adaptation of agrobiodiversity management across a global set of research regions. Glob Environ Chang 22:623-639

Jones DT, Eggleton P (2000) Sampling termite assemblages in tropical forests: testing a rapid biodiversity assessment protocol. J Appl Ecol 37:191-203

Jones DT, Susilo F-X, Bignell DE, Suryo H, Gillison AW, Eggleton P (2003) Termite assemblage collapses along a land use intensification gradient in lowland central Sumatra, Indonesia. J Appl Ecol 40:380-391

Kapos V, Jenkins MD, Lysenko I, Ravilious C, Bystriakova N, Newton A (2001) Forest biodiversity indicators: tools for policy-making and management. United Nations Environment Programme. World Conservation Monitoring Centre, Cambridge

Kessler M, Abrahamczyk S, Bos M, Buchori D, Putra DD, Gradstein SR, Höhn P, Kluge J, Orend F, Pitopang R, Saleh S, Schulze CH, Sporn SG, Steffan-Dewenter I, Tjitrosoedirko SS, Tscharntke T (2011) Cost-effectiveness of plant and animal biodiversity indicators in tropical forest and agroforest habitats. J Appl Ecol 48:330-339

Kleyer M (2002) Validation of plant functional types across two contrasting landscapes. J Veg Sci 13:167-178

Knollová I, Chytrý M, Tichý L, Hájek O (2005) Stratified resampling of phytosociological databases: some strategies for obtaining more representative data sets for classification studies. J Veg Sci 16:479-486

Lawton JH, Bignell DE, Bolton B, Bloemers GF, Eggleton P, Hammond PM, Hodda M, Holt RD, Larsen TB, Mawdsley NA, Stork NE, Srivastiva DS, Watt AD (1998) Biodiversity inventories, indicator taxa and effects of habitat modification in tropical forest. Nature 391:72-76

Le HD, Smith C, Herbohn J, Harrison S (2012) More than just trees: assessing reforestation in tropical developing countries. J Rural Stud 28:5-19

Loreau M, Naeem S, Inchausti P, Bengtsson J, Grime JP, Hector A, Hooper DU, Huston MA, Raffaelli D, Schmid B, Tilman D, Wardle DA (2001) Biodiversity and ecosystem functioning: current knowledge and future challenges. Science 26:804-808

MacNally R, Fleishman E (2004) A successful predictive model of species richness based on indicator species. Conserv Biol 18:646-654

Magurran AE, Baillie SR, Buckland ST, Dick JMcP, Elston DA, Scott EM, Smith RI, Somerfield PJ, Watt AD (2010) Long-term datasets in biodiversity research and monitoring: assessing change in ecological communities through time. Trends Ecol Evol 25:574-582

Meijaard E, Sheil D (2012) The dilemma of green business in tropical forests: how to protect what it cannot identify? Conserv Lett 5:342-348

Noss RF (1999) Assessing and monitoring forest biodiversity: a suggested framework and indicators. For Ecol Manag 115:135-146

Palm C, Vosti SA, Sanchez PA, Ericksen PJ (eds) (2005) Slash-and-burn agriculture, the search for alternatives. Columbia University Press, New York

Parker VT, Schile LM, Vasey C, Callaway JC (2011) Efficiency in assessment and monitoring methods: scaling down gradient-directed transects. Ecosphere 2:99. doi:10.1890/ES11-00151.1 
Sanchez PA, Palm CA, Vosti SA, Tomich TP, Kasyoki J (2005) Alternatives to slash-and-burn, challenges and approaches of an international consortium. In: Palm C, Vosti SA, Sanchez PA, Ericksen PJ (eds) Slash-and-burn agriculture, the search for alternatives. Columbia University Press, New York, pp 3-37

Sarkar S, Margules CS (2002) Operationalizing biodiversity for conservation planning. J Biosci (Suppl 2) 27:299-308

Sarkar S, James J, Fuller T, Kelley C, Garson J, Mayfield M (2005) Effectiveness of environmental surrogates for the selection of conservation area networks. Conserv Biol 19:815-825

Sauberer N, Zulka K-P, Abensperg-Traun M, Berg H-M, Bieringer G, Milasowszky N, Moser D, Plutzar C, Pollheimer M, Storch C, Tröstl R, Zechmeister H, Grabherr G (2004) Surrogate taxa for biodiversity in agricultural landscapes in eastern Austria. Biol Conserv 117:181-190

Schulze CH, Waltert M, Kessler PJA, Pitopang R, Shahabuttin, Veddeler D, Mühlenberg M, Gradstein SR, Leuschner C, Steffan-Dewenter I, Tscharntke T (2004) Biodiversity indicator groups of tropical land use systems: comparing plants, birds, and insects. Ecol Appl 14:1321-1333

Sheil D, Burslem DFRP (2003) Disturbing hypotheses in tropical forests. Trends Ecol Evol 18:18-26

Soriç B (1989) Statistical "discoveries" and effect size estimation. J Am Stat Assoc 84:608-610

Stewart-Oaten A (1995) Rules and judgements in statistics: three examples. Ecology 76:2001-2009

Swift M, Bignell D (eds) (2001) Standard methods for the assessment of soil biodiversity and land use practice. International Centre for Research in Agroforestry, South East Asian Regional Research Programme. ASB-lecture note 6B, Bogor, Indonesia. http://www.fao.org/ag/agl/agll/soilbiod/docs/ manual-soil\%20bioassessment.pdf. Accessed 6 May 2012

United Nations Environment Program, Convention on Biological Diversity (UNEP/CBD) (2003). Proposed biodiversity indicators relevant to the 2010 target. UNEP/CBD/SBSTTA/9/INF/26. UNEP/CBD, Montreal

United Nations Environment Program, Convention on Biological Diversity (UNEP-CBD) (1996) Assessment of biological diversity and methodologies for future assessments. UNEP/CBD/SBSTTA/2/2. UNEP-CBD, Montreal

van Teeffelen AJA, Cabeza M, Moilanen A (2006) Connectivity, probabilities and persistence: comparing reserve selection strategies. Biodivers Conserv 15:899-919

Villaseñor JL, Ibarra-Manriquez G, Meave JA, Ortiz E (2005) Higher taxa as surrogates of plant biodiversity in a megadiverse country. Conserv Biol 19:232-238

Watt AD (1998) Measuring disturbance in tropical forests: a critique of the use of species-abundance models and indicator measures in general. J Appl Ecol 35:467-469

Watt AD, Argent G, Bibby C, Carter Lengeler J, Eggleton P, Garwood N, Gillison AN, Hawthorne W, Healey J, Hall J, Jones JS, Kapos V, Lyal C, Moss D, Newton AC, Philips O, Sheil D (1998). Evaluation and development of methods of rapid biodiversity assessment in relation to the conservation of biodiversity in tropical moist forests. Report to DFID, Oxford

Wessels KJ, Van Jaarsveld AS, Grimbeek JD, Van der Linde MJ (1998) An evaluation of the gradsect biological survey method. Biodivers Conserv 7:1093-1121

Westoby M, Falster D, Moles AT, Vesk PA, Wright I (2002) Plant ecological strategies: some leading dimensions of variation between species. Annu Rev Ecol Syst 33:125-159

Wright SJ, Muller-Landau HC (2006) The future of tropical forest species. Biotropica 38:287-301

Wright IJ, Reich PB, Westoby M, Ackerly DD, Baruch Z, Bongers F, Cavender-Bares J, Chapin FS, Cornelissen JHC, Diemer M, Flexas J, Garnier E, Groom PK, Gulias J, Hikosaka K, Lamont BB, Lee T, Lee W, Lusk C, Midgley JJ, Navas M-L, Niinemets Ü, Oleksyn J, Osada N, Poorter H, Poot P, Prior L, Pyankov VI, Roumet C, Thomas SC, Tjoelker MG, Veneklaas E, Villar R (2004) The world-wide leaf economics spectrum. Nature 428:821-827 